\title{
The impact of competition with China in the US market on innovation in Mexican manufacturing firms
}

\author{
Liliana Meza-González ${ }^{1}$ and Jaime Marie Sepulveda ${ }^{2^{*}}$ (I)
}

\author{
*Correspondence: \\ jaime.sepulveda@aggienetwork. \\ com \\ ${ }^{2}$ Texas A\&M University, College \\ Station, USA \\ Full list of author information \\ is available at the end of the \\ article
}

\begin{abstract}
Using data from 6378 Mexican firms for the 2012-2013 period, this paper estimates the effect of competition with China for the US market on the innovation efforts of the Mexican manufacturing sector. After controlling for the influence of several variables, we find a U-curve shaped relationship between foreign competition (measured by the China effect) and the innovation of Mexican manufacturing firms in products, in processes, and for the world. Given that the quadratic positive effect is much larger than the negative linear effect, we conclude that an Escape-Competition effect dominates when Mexican firms are fighting for a larger market share with China in the US.
\end{abstract}

Keywords: Foreign competition, Technological innovation, Manufacturing sector, Developing country

JEL Classification: L6, O3, O5, F6

\section{Introduction}

Through globalization and the expansion of international trade, developing countries have had the opportunity to internationalize by participating in the global economy via foreign direct investment (FDI), the incorporation in multinational supply chains, and importing and exporting activities. Since Mexico liberalized its economy in the 1980s and China joined the World Trade Organization (WTO) in 2001, both countries have seen tremendous increases in their exports. Mexico and China offer low-cost labor and specialize in manufacturing with the United States (US) as an important export destination. Empirical research has found that Mexican manufacturing firms that are internationalized, particularly through export activities, are more likely to innovate than their domestic-oriented counterparts.

This paper explores the question of whether competition from China for US market share increases innovation among Mexican manufacturing firms. There is little research on the impact of Chinese competition on innovation. Therefore, the literature on the effect of China's emergence as a major global exporter and the leading theories regarding competition and innovation are analyzed to address the research question. This investigation led to the hypothesis that increased competition from China for US market share 
would increase innovation in Mexican manufacturing firms. However, we find that this phenomenon only occurs after an initial period of declining innovation.

Technological innovation is considered a relevant means of increasing firms' market shares and a key factor to boost economic growth. This indicates that innovation generates positive externalities which benefit society as a whole. The fact that Mexican firms increase their innovation efforts due to increased competition with China in foreign markets can make a significant impact on the negotiations of trade agreements with the US and other countries where China is introducing new export items and where the Mexican productive sector could play an important role.

According to the Oslo Manual, innovation is defined as "the generation of new products and processes technologically implemented and substantive technological improvements in products and processes" (OECD 1997, p 31). Therefore, when analyzing innovation at the firm level, it is recommended to focus on the results rather than on indirect measures of innovation such as Research and Development (R\&D) effort or patent registration. ${ }^{1}$

This paper is organized as follows. Part I is the introduction, and Part II is a thorough literature review. Part III provides the theoretical framework. Part IV describes the data set used in this analysis, the methodology, and some descriptive statistics. Part V discusses the regressions that were conducted along with the results. Part VI concludes the paper and considers policy implications.

\section{Literature review}

Existing research about China's effect on Mexico and Latin America tends to focus on: (1) trade and FDI (Gallagher and Porzecanski 2008; Sargent and Matthews 2009); (2) market share (Gallagher and Porzecanski 2008); Lall and Weiss 2007); and (3) wages and employment rates (Caamal-Olvera and Rangel-González 2015; Ma and Wooster 2009; Mendoza Cota 2016). Within the literature, there is debate over whether China's emergence as a major global exporter has positively or negatively impacted Latin America, and there is little research on how competition from China affects innovation. Largely due to an abundance of low-cost, rural labor, China's manufactured exports grew 16.6\% annually over 1990-2002 (Lall and Weiss 2007). On one hand, China's economic growth has been positive for Latin America and the Caribbean (LAC) because it has been associated with an increase in LAC exports to China and Chinese FDI to the region (Gallagher and Porzecanski 2008).

Excluding Mexico, Chinese exports do not pose a significant threat to LAC countries for world market share since LAC countries mainly export primary goods and raw materials while China and Mexico specialize in manufactured goods (Gallagher and Porzecanski 2008). Consequently, Mexico has been losing (i.e., growing more slowly) in US market share, FDI, and competitiveness compared to China.

Drawing from the business literature, China is a "competitive threat" when it gains export market share at the expense of another country losing it (Lall and Weiss 2007).

\footnotetext{
${ }^{1}$ According to Becheikh et al. (2006), patent registration shows the inventive capacity of a company and not necessarily its propensity to generate innovations. On the other hand, $R \& D$ effort is considered an input of innovation rather than a result.
} 
China's rapid export expansion over the 1990s and 2000s raised concerns among LAC countries that they could lose overseas market share, particularly in the United States. Lall and Weiss (2007) analyze the competitive threat between China and LAC countries according to the similarity of their export structures at the technological and product levels. They evaluate the intensity of the competitive threat from China as either: (1) no threat, (2) partial threat, (3) direct threat, (4) reverse threat, i.e., where China is losing market share, or (5) mutual withdrawal. The majority of LAC countries' trade structures are more complementary than competitive with China because they export primary goods and resource-based products while China exports more manufactured goods. Over 1990-2002, the percent of LAC exports to the US in the direct threat category drastically reduced from 29.6 to 7.6\% (Lall and Weiss, 2007). Like China, Mexico predominantly exports manufactured goods. However, in 2002, only 3\% of Mexico's exports to the US were directly threatened by Chinese competition (Lall and Weiss 2007).

Since China's accession to the WTO in 2001, imports from China to the US have increased at a greater rate than those from Mexico (Ma and Wooster 2009). Within the literature, competition from China faced by Mexico is classified as either direct (in Mexico) or indirect (via the US market). The majority of the research regarding the China effect on Mexico focuses on the implications of Chinese competition for labor indicators such as employment rates and wages. Multiple studies find that imports from China have negatively impacted the labor market in Mexico as well as the US counties located on the US-Mexico border (Caamal-Olvera and Rangel-González 2015; Ma and Wooster 2009; Mendoza Cota 2016).

Direct competition from China, measured as imports, has a negative and statistically significant correlation with employment rates and wages in both Mexico and US counties along the US-Mexico border (Caamal-Olvera and Rangel-González 2015; Ma and Wooster 2009). In the US, the impact of increased imports from China after 2001 was greater in areas with less diverse economies that rely more heavily on manufacturing (Ma and Wooster 2009). Likewise, in Mexico, increased imports from China have had a negative impact on the demand for labor and wages (Caamal-Olvera and RangelGonzález 2015).

Considering China and Mexico, both offer abundant low-cost labor, have similar export profiles, and directly compete in the manufacturing industry for US market share; it is important to also analyze the impact of indirect competition from China via the US market on Mexico. However, empirical studies yield conflicting results. Caamal-Olvera and Rangel-González (2015), who use panel data from 1990 to 2013, do not find a statistically significant relationship between indirect competition from China on Mexican employment or wages. Mendoza Cota (2016), who uses a time series model with data from 2004 to 2012, also explores the impact of Chinese manufacturing exports to the US on employment rates in the Mexican manufacturing industry. His results reveal that a decreased demand for labor in Mexican manufacturing is associated with an increase in Chinese manufactured exports to the US, lower manufacturing wages in China relative to Mexico, and a decrease in the yuan-to-dollar exchange rate relative to the pesoto-dollar (Mendoza Cota 2016). These results may vary due to distinct timeframes or control variables. 
There is a gap in the literature regarding the relationship between competition from China and innovation. Although not related to Mexico or Latin America, there is one notable study that explores the effect of direct competition from Chinese imports on innovation in Europe (Bloom et al. 2016). This paper analyzes the effects of Chinese imports on innovation, IT, and productivity in 12 European countries with industryand firm-level panel data from 1996 to 2007. Innovation is measured by the number of patents. Surviving firms face greater exposure to Chinese competition and experienced higher levels of technical change, as measured by total factor productivity (TFP), IT intensity, management practices, and R\&D expenditures. Employment levels and company survival rates decrease for low-tech firms in industries that experience greater exposure to Chinese competition. Thus, employment is reallocated toward more hightech firms. Bloom et al. (2016) determines that increasing trade with China contributes to greater innovation, higher productivity through faster technical change, and the implementation of new technologies in the European countries included in the study.

The literature review concludes with an analysis of two empirical studies (Alvarez and Robertson 2004; Meza-González 2017) which explore the impact of internationalization on manufacturing innovation in Mexico. These works are important references for defining and measuring key variables as well as offering insight into the expected impact of increased competition from China in the US market on innovation in Mexican manufacturing firms.

Alvarez and Robertson (2004) define internationalization as the exposure to foreign markets through FDI, exporting, and importing intermediate inputs. Meza-González (2017) uses a similar definition with the addition of outsourcing, which is an important part of the Mexican manufacturing industry. Unlike studies that use the number of patents to measure innovation, Meza-González (2017) utilizes results-focused measures of innovation. These include product and process innovation for the company, for Mexico, and for the world. Alvarez and Robertson (2004) measure innovation through product design, existence of an R\&D laboratory, process innovation, ISO 9000 certification, foreign technical licenses, product innovation, and organizational administration innovation. Both studies find internationalization is positively related to innovation and that exporting has the greatest impact on innovation.

Alvarez and Robertson (2004) also explore the effect of internationalization on manufacturing innovation in Chile. This allows them to analyze the long- and short-term impacts of internationalization since Chile's economy liberalized in the 1970s and Mexico's in the 1980s-1990s. With the Chilean data included, they argue that exporting might have little effect on innovations that are associated with long-term gains in productivity. Alvarez and Robertson (2004) also explore the innovative differences between manufacturing firms that export to other developing countries versus to developed countries, like the US. For Mexico, plants that export to developed countries are statistically more likely to innovate in new products and tools and to reorganize production.

Meza-González (2017) investigates the relationship between internationalization and innovation in the Mexican manufacturing industry with data from 2285 manufacturing firms from 2008 to 2009. Although a short time period, the results show that internationalized companies are more likely to innovate than their strictly domesticoriented counterparts. Firms that export are $148.5 \%$ more likely to create innovations 
for the world. Companies that demonstrate innovative efforts, as indicated by the presence of an R\&D laboratory, are more likely to innovate regardless of their relationship with international markets. Internationalization does not have a statistically significant impact on product or process innovation. Outsourcing has a negative relationship with innovation, such that outsourcing firms (known as "maquiladoras") are $45.25 \%$ less likely to innovate. Meza-González (2017) argues that the maquiladora model is not conducive to long-term economic growth. She also proposes that exporting companies are more likely to generate innovations for the world due to the competition in international markets and the need to decrease costs.

\section{Theoretical framework}

Within business and economics literature, there is extensive empirical and theoretical research on competition and innovation. Yet, there is no definitive consensus on the nature of the relationship and different studies offer contradictory findings (Chen 2017). The principle models for describing the relationship between competition and innovation fall into three categories: (1) the Schumpeterian effect, which is linear and negative, (2) the Escape-Competition effect, which is linear and positive, and (3) the Inverted-U Relationship. The inverted-U theory is the most generally accepted model for competition and innovation. However, recent studies have begun to challenge the inverted- $U$ in favor of either a positive (Gorodnichenko et al. 2010) or negative relationship (Hashmi 2013). This debate illustrates the complex relationship between competition and innovation.

Schumpeter and Joseph (1943) propose that as competition increases, innovation decreases (Schumpeter and Joseph 1943). This phenomenon is referred to as the Schumpeterian effect (Aghion et al. 2005; Chen 2017; Gilbert and Newbery 1982). Under this model, firms are motivated to innovate by the possibility of collecting monopoly rents, i.e., financial returns (Chen 2017). That is why innovation is high when competition is low. When competition is high, post-innovation rents are lower, and there is less incentive for firms to innovate (Aghion and Griffith 2005). This theory implies that higher competition leads to less innovation and slower productivity growth. Essentially, perfect competition is not ideal to promote innovation.

According to Aghion et al. (2005), the Schumpeterian model confirms the "theoretical prejudices of the era" when it was developed. Schumpeter and Joseph (1943) view capitalism as a system where incumbents with market power are threatened by existing competitors and new entrants. In his study, Schumpeter focuses on the costs of innovation and its benefits (Carlin et al. 2004). He stresses that innovation is expensive and that it is motivated by the potential rewards that successful innovation would produce as well as the need "to maintain existing rents in the face of competitive threat" (Carlin et al. 2004). Large firms in concentrated markets are the most likely to innovate since they have the most to gain from innovative activity (Schumpeter and Joseph 1943). Several later studies (Aghion and Howitt 1992; Dixit and Stiglitz 1977; Gilbert and Newbery 1982; Romer 1990; Salop 1977) build on Schumpeter's work and confirm the negative relationship between competition and innovation. Due to potential endogeneity between competition and innovation, Aghion et al. (2005) suggest there may be a bias toward finding a 
negative association between competition and innovation if greater levels of innovation actually lower the competition.

Many economists believe that competition stimulates innovation and economic growth by compelling firms to lower costs and develop new products (Chen 2017). Consequently, the Escape-Competition effect, which demonstrates a positive relationship between competition and innovation, is the most intuitive of the three models. It shows that firms with similar levels of technological sophistication, described as "neck-andneck" firms, increase innovation to escape, or get ahead of, competition (Aghion et al. 2005). More competition leads to greater efficiency, innovation, and faster productivity growth.

Arrow (1962) is one of the early and influential studies in this school of thought. Arrow's model is completely reversed from the Schumpeterian model such that monopolist firms have lower incentives to innovate than firms in more competitive industries since they already earn high profits. Firms in competitive industries would realize greater marginal gains from innovation than monopolies, which increases motivation to pursue innovative activities. New entrants have stronger incentives to innovate than incumbents due to a potentially greater marginal gain (Arrow 1962).

Blundell et al. (1999) also find a positive relationship between competition and innovation. Their results indicate that larger firms with greater market shares are more likely to innovate in a preemptive fashion to avoid potential competitive threats. Such firms attempt to escape competition through innovation. Additionally, Blundell et al. (1999) argue that the rate of innovation is higher in industries with more intense competition. In more competitive industries, the positive linear relationship between competition and innovation is steeper (Blundell et al. 1999). Recent studies (Bloom et al. 2016; Gorodnichenko et al. 2010) find evidence of a positive relationship between foreign competition and innovation.

Scherer (1967) and Kamien and Schwartz (1972) establish the early theoretical framework for a non-monotonic relationship between competition and innovation with an inverted-U shape. These works investigate how R\&D spending and innovation are realized under different competitive market structures assuming no knowledge spillovers between firms. They find that innovation initially rises when competition increases and then falls at higher levels of competition. In the first-half of the inverted-U, increased competition is associated with greater innovative efforts, measured in R\&D spending, if each firm can anticipate that the financial reward will cover the initial costs. In the second-half of the inverted- $U$, as competition continues to increase through either a greater number of market participants or a shrinking pool of players, there is more price competition. Thus, the anticipated benefits from innovating are less than expected R\&D costs, which leads to reduced innovation and firms dropping out of the market.

Aghion et al. (2005) offer an empirical study of competition and innovation that reveals an inverted-U shape with panel data from 1973 to 1994 for 311 manufacturing firms in the UK. Aghion et al.s theoretical analysis of the inverted-U relationship is based on the technological sophistication of the firms in a particular industry. Firms that are technologically on par are considered "neck-and-neck" and their industry is considered "leveled." Conversely, "unleveled" industries are characterized by firms with a technological disparity such that the advanced firm is the "leader" and the follower is the "laggard." 
Under the rising portion of the inverted-U, there is initially low product market competition, and there is little incentive for neck-and-neck firms to innovate (Aghion et al. 2005). An industry does not leave the leveled state until one of the neck-and-neck firms innovates. At this point, the rate of innovation rises and the sector is unleveled. However, the industry quickly returns to the leveled state once the laggard firm innovates. In the first-half of the inverted- $U$, industries are predominantly in the leveled state, where they are impacted by the Escape-Competition effect. This is defined as the phenomenon of competition increasing the incremental profit earned from innovation (Aghion et al. 2005). With these conditions, innovation leads to substantial incremental profits, giving firms a large incentive to innovate.

Under the falling portion of the inverted-U, there is initially high competition and the industry is in an unleveled technological state (Aghion et al. 2005). As competition increases, average innovation declines and industries are slow to leave the unleveled state. In this half of the inverted-U, "the Schumpeterian Effect is at work on the laggard, while the leader never innovates." Increased competition discourages innovation for laggard firms due to the diminishing incremental profit that would be earned from innovating.

The balance between the Escape-Competition effect and the Schumpeterian effect changes between levels of low and high competition and yields the inverted- $\mathrm{U}$ relationship (Aghion et al. 2005). Aghion et al. (2005) argue that the rising portion of the inverted- $U$ is steeper when the Escape-Competition effect is stronger. This occurs among more neck-and-neck firms that are closer to the technological frontier of their industry. This argument is consistent with Baily and Gersbach (1995), which find that "head-to-head" competition leads to faster innovation. Aghion et al. (2005) find that the peak of the inverted-U occurs at a higher degree of both competition and innovation in more neck-and-neck industries. The results of Aghion et al. (2005) also show that technologically leveled industries demonstrate greater innovation at every level of competition compared to technologically unlevelled industries.

There are two main studies, Gorodnichenko et al. (2010) and Hashmi (2013), that fail to support the inverted- $U$ relationship between competition and innovation as proposed by Aghion et al. (2005). The first study (Gorodnichenko et al. 2010) explores the impact of foreign competition on domestic innovation and finds no evidence of an inverted-U relationship. This result remains robust even when firms are analyzed separately based on their technological sophistication as either advanced or laggard. Gorodnichenko et al. (2010) conclude that "there is no support for an inverted-U relationship between foreign competition and innovation." Rather, for both the manufacturing and the service sectors, the results indicate a positive relationship between foreign competition and innovation characterized by the Escape-Competition effect.

The second study (Hashmi 2013) replicates the empirical work of Aghion et al. (2005), which analyzes UK manufacturing firms, to analyze US manufacturing firms. The results indicate a negative relationship characteristic of the Schumpeterian effect between product market competition and innovation. Hashmi (2013) describes the relationship as "mildly negative" because the results are statistically significant, but small in magnitude. To reconcile this difference from Aghion et al. (2005) inverted-U model, Hashmi (2013) assumes that UK manufacturing firms are more technologically neck-and-neck than US 
firms. Alternative explanations include possible differences in the samples. Aghion et al. (2005) analyze data from 311 UK manufacturing firms. Hashmi (2013) uses data from 7789 US manufacturing firms.

Hashmi (2013) empirical results differ from those of Aghion et al. (2005) as well as the many studies that find a positive relationship between competition and innovation. Hashmi (2013) determines that the US industries are more "unleveled" while the UK industries are more "leveled" through an analysis of the technology gap between industry leaders and laggards. Since there is a higher average technology gap in US industries than in the UK, it produces the negative relationship between competition and innovation seen in the US data. This supports the Schumpeterian hypothesis that less competitive industries are more innovative (Hashmi 2013). Hashmi (2013) also raises the concern that the inverted-U model found by Aghion et al. (2005) is based on an analysis conducted at the aggregate rather than the industry level, whereas what is actually empirically tested is the industry-level relationship between competition and innovation. According to Hashmi (2013) analysis, the industry-level relationships between competition and innovation in Aghion et al. (2005) data are either positive or negative rather than U-shaped.

\section{Data, descriptive statistics, and methodology}

\subsection{Data}

The firm-level data used in this paper to analyze the relationship between the China effect (competition with China for the US market) and technological innovation in Mexican manufacturing firms (measured by the generation of new products and processes) are from the 2014 Survey of Research and Technological Development (ESIDET). This survey, conducted by the Mexican National Institute of Statistic and Geography (INEGI), collects firm-level data for the years 2012 and 2013. The objective of the ESIDET is to capture and generate information related to the human and financial resources dedicated to research and technology development activities in the firms. The companies included in the ESIDET sample belong to the following sectors: non-profit private, higher education, governmental, and productive sectors. This research exclusively focuses on the firms in the productive sector which manufacture goods. The ESIDET follows the methodology of the Frascati Manual of the Organization for Economic Co-operation and Development (OECD), and has been conducted every 2 years during the period of 2000-2018. At the time this research was performed, the INEGI had not yet released the results of the 2016 ESIDET. The ESIDET is applied to a representative sample of firms at a national level that have more than 20 employees in Mexico. Multiple ESIDET samples are not used because it is impossible to identify and track individual firms over time using this survey. ${ }^{2}$ Given that innovation is a dynamic process, we acknowledge that the use of only 2 years of information could limit the scope of our analysis.

To measure the innovation results of the ESIDET manufacturing firms, three selfreported variables are used: (1) innovation in products, (2) innovation in processes, and (3) innovation for the world. A product innovation is reported when a firm declares it

${ }^{2}$ ESIDET assigns each surveyed firm a consecutive identification number in every survey conducted. This makes it impossible to follow firms through time, at least through 2013. 
has significantly modified one of the products it has previously produced, either technologically or regarding the provided uses. A process innovation is reported when a firm declares it has made improvements to manufacturing processes that have reduced costs. An innovation for the world is reported when a firm declares it has created a product that did not previously exist or when it has improved a process in a way that was previously unknown. Although these variables may include self-reported biases, they are considered relatively strong measures of innovation since we are focused on innovative results, as the OECD recommends. This approach is also followed by Gorodnichenko et al. (2010). The self-reported innovation data in the ESIDET are supported by further information in the survey; therefore, the potential impact of self-reporting bias is considered minimal.

To measure the China effect, 2013 data on about US imports and its origins published by the US International Trade Commission (USITC) are used. US international trade statistics and US tariff data are available to the public through the USITC's Interactive Tariff and Trade DataWeb. ${ }^{3}$ All trade data have been compiled from official data retrieved from the US Census Bureau (an agency within the US Department of Commerce). US import statistics, US export statistics, US tariffs, US future tariffs, and US tariff preference information is available on the web through a self-service, interactive basis. The USITC DataWeb responds to user-defined queries integrating international trade statistics with complex tariff and customs treatment and allows users to create and save customized country and product lists. International trade data are available for 1989 to the present on a monthly, quarterly, annual, or year-to-date basis and can be retrieved in a number of classification systems, including the Harmonized Tariff Schedule (HTS), the Standard International Trade Classification (SITC), or the North American Industry Classification System (NAICS). Pre-defined reports on international trade statistics are also available by geographic region and partner country. Current US tariffs, which are maintained and published by the USITC as a statutory responsibility, can be accessed via the USITC DataWeb and retrieved with relevant international trade data.

Given that the ESIDET organizes industries according to the OECD classification, a table of equivalencies with NAICS was generated to combine the two data sets. This table is available upon request. To measure the China effect, the percentage of US imports that originate in China is calculated by OECD industry. This is one of the independent variables used in the econometric estimations. The rest of the independent variables are constructed using ESIDET information.

\subsection{Descriptive statistics}

To better understand the effect of the competition with China on the generation of new products and processes, we distinguish between "internationalized" and "noninternationalized" companies. For purposes of this investigation, an internationalized company is a firm which sells part of its production to international markets (exporter) or receives part of its capital from another country (inward FDI). Outsourcing firms, which have over $95 \%$ foreign capital and export over $90 \%$ of their

\footnotetext{
${ }^{3}$ https://dataweb.usitc.gov/.
} 
Table 1 Basic statistics-expanded data with 2014 ESIDET factors Source Author calculations based on the 2014 ESIDET, INEGI

\begin{tabular}{llrc}
\hline & Variables & Avg. & Std. dev. \\
\hline Firm level & Firm with 100\% foreign capital & 7.98 & 0.271 \\
& Firm with mixed capital & 2.88 & 0.167 \\
& Firm with only national capital & 89.14 & 0.331 \\
& Exporting firm & 16.26 & 0.369 \\
& Public firm & 0.32 & 0.056 \\
& Firm as part of a corporation & 17.00 & 0.375 \\
& Outsourcing firm (maquila) & 2.89 & 0.209 \\
& Average size (in number of employees) & 183.73 & 1166.55 \\
& Concentration measure (avg \% of income of four largest & 56.56 & 0.248 \\
& firms) & & \\
& Percentage of US imports by industry from China & 29.10 & 0.195 \\
\hline
\end{tabular}

a The concentration measure is calculated by industry

Table 2 Innovation variables, by firm type, 2014 (percentages) Source: Author calculations based on the 2014 ESIDET, INEGI

\begin{tabular}{|c|c|c|c|c|c|c|}
\hline & \multicolumn{2}{|l|}{ Total } & \multicolumn{2}{|c|}{ Internationalized firms } & \multicolumn{2}{|c|}{$\begin{array}{l}\text { Non- } \\
\text { internationalized } \\
\text { firms }\end{array}$} \\
\hline & Avg. & Std. dev. & Avg. & Std. dev. & Avg. & Std. dev. \\
\hline Innovation in product & 6.25 & 0.242 & 10.64 & 0.308 & 4.25 & 0.202 \\
\hline Innovation in process & 3.94 & 0.194 & 7.44 & 0.262 & 2.33 & 0.151 \\
\hline Innovation for the world & 4.63 & 0.21 & 6.17 & 0.241 & 3.92 & 0.194 \\
\hline Innovation project & 8.43 & 0.277 & 14.99 & 0.357 & 5.43 & 0.227 \\
\hline Area of R\&D & 4.04 & 0.197 & 8.71 & 0.282 & 1.89 & 0.136 \\
\hline
\end{tabular}

production, are also considered internationalized. This definition does not include companies that invest part of their capital abroad (outward FDI). Table 1 provides basic information about the sample of firms used in this research.

The total number of sample companies is 6378 . According to Table 1 , only $7.98 \%$ of the companies from the sample (expanded with expansion factors from the ESIDET) have $100 \%$ foreign capital, while only $2.88 \%$ have mixed capital (national and foreign). This implies that $89.14 \%$ of the sample comprises companies with $100 \%$ Mexican capital. In addition, $16.26 \%$ of the expanded samples are exporting companies. Only $2.89 \%$ of the samples are outsourcing companies (i.e., companies that have over $95 \%$ of foreign investment and export over $90 \%$ of their production). Finally, $17.00 \%$ of the companies are part of a corporation. The average size (in personnel) of the sample companies is 184 employees. On average, the largest four companies of each manufacturing sector included in the analysis hold $56.56 \%$ of the total sector income, which indicates market concentration.

Table 2 shows the basic statistics of innovation variables related to the generation of new products and processes and disaggregates the results by internationalized and non-internationalized companies. According to the data, $6.25 \%$ of all companies in the expanded sample engage in product innovation in 2012 or 2013, while only $3.94 \%$ 
engage in process innovation. The data further show that $4.63 \%$ of the firms in the sample declare that they engage in innovation for the world (versus innovation for the firm or for the country). The ESIDET also includes questions regarding the intention to innovate in the companies. $8.43 \%$ of the sample companies reported that they have worked on an innovation project. Finally, the table shows that only $4.04 \%$ of the firms report having a designated area for R\&D.

To understand the innovative efforts of internationalized firms and to compare them to the innovative efforts of the non-internationalized firms, the basic statistics of the innovation variables according to company type were obtained. This information is also depicted in Table 2. The fact that the companies with a relationship with international markets perform better in innovation than the companies without exports or foreign capital draws attention. The descriptive statistics suggest that having contact with international markets promotes greater levels of innovation. To better understand the relationship between internationalization and innovation, econometric estimates are carried out which control for the effect of other factors on product and process innovation such as company size, innovative effort, and the competition grade of the industry in which each company operates.

In the sample, there are 2742 internationalized companies and 3636 non-internationalized companies. Table 2 indicates that during 2012 and 2013, 10.64\% of the internationalized companies generated product innovations, compared to only $4.25 \%$ of the non-internationalized companies. On the other hand, it also indicates that $7.44 \%$ of the internationalized companies generated process innovations, compared to only $2.33 \%$ of the non-internationalized companies. Regarding the generation of innovations for the world, $6.17 \%$ of the internationalized companies declared to have generated this type of innovation in 2012 or 2013 compared to only $3.92 \%$ of the non-internationalized companies. Moreover, data from Table 2 indicate that companies with a relationship with international markets tend to engage in innovation projects more frequently and to invest more in an $R \& D$ area inside the firm when compared to their non-internationalized counterparts. Consequently, the estimations in this analysis consider the effect of internationalization on innovation to minimize the impact of potential biases.

\subsection{Methodology}

In order to understand the effect of competition with China for the US market on the innovative efforts of Mexican manufacturing firms, and since the analyzed dependent variables are discreet (i.e., binary), the technique of logistic regression is used. This approach allows us to determine the level of association between the independent and dependent variables as well as to estimate the specific weight of each independent variable while controlling for the other variables in the model. Three different logistic regressions are estimated in which the dependent variables correspond to each of the innovation variables discussed in the previous section, i.e., product innovation, process innovation, and innovation for the world.

The independent variables are consistent with those commonly used in the literature to capture innovation results within firms, i.e., the company's capital type, exporting activity, being part of a corporation and company size. A variable to identify outsourcing companies is also considered in the regressions because Meza-González (2017) finds 
that this characteristic is negatively and significantly related to the innovation results of Mexican manufacturing firms. An additional explanatory variable is included to control for the R\&D efforts of firms, i.e., the presence of an R\&D laboratory in the production unit. This variable is highly correlated with the share of a firm's labor force made up of skilled workers relative unskilled workers. The share of highly skilled personnel in the firm is used by Gorodnichenko et al. (2010) as one of the explanatory variables in the innovation regressions. This study uses the existence of an R\&D laboratory within the firm instead. Another variable that is commonly considered to be related to the innovation results of firms is their age. This variable is not included in this analysis because it is not considered in the ESIDET database. Other factors such as tax structure, government incentive programs, bureaucracy, etc., could also make an important impact on the dependent variables. These factors are being considered for future research.

Macroeconomic conditions are also believed to be relevant to firms' decisions surrounding innovation activities. We assume that macroeconomic conditions affect different firms in a rather similar way in a given year. However, if we were analyzing innovation decisions over time, the use of time fixed effects would have been implemented to control for varying macroeconomic conditions in different years. A variable that measures the degree of internal competition at the industry level $\left(C_{i}\right)$ is also included as a regressor. It is estimated by subtracting the percentage of income in each industry generated by the four largest firms $\left(H_{i}\right)$ from one, such that:

$$
C_{i}=1-H_{i}
$$

In this equation, $H_{i}$ is the proportion of income generated by the four largest companies in industry $i$, and $C_{i}$ is a measure of internal competition within an industry.

It is important to highlight that internal competition is distinguished from external competition (i.e., the China effect) since Mexican firms competing in the internal market are likely characterized by similar levels of technological sophistication levels, while Mexican firms competing in the US market are likely to possess different levels of technological sophistication when compared to Chinese firms. This means that internal (domestic) competition is more leveled while external competition is more unleveled. These considerations support the results of this analysis and are further addressed in the policy implications discussion of the conclusion.

Finally, in the logistic regressions, competition with China is measured as the percentage of US imports from China. This variable is calculated at the industry level with data from the US where industry is defined by the OECD classification. In a logistic regression, a logistic transformation of the following type to the dependent variable is applied: $\ln (p / q)$, where: $p=$ the probability that the event occurs, and $q=(1-p)$ the probability that nothing occurs. On this basis, the equation of the logistic regression is represented as follows:

$$
\ln (p / q)=\beta_{0}+\beta_{1} X_{1}+\beta_{2} X_{2}+\beta_{3} X_{3}+\cdots+\beta_{n} X_{n}+\varepsilon_{i} .
$$

Which is equivalent to:

$$
p / q=\mathrm{e}^{\left(\beta_{0}+\beta_{1} X_{1}+\beta_{2} X_{2}+\beta_{3} X_{3}+\cdots+\beta_{n} X_{n}+\varepsilon_{i}\right)}
$$

In the equation, the $\beta_{i}$ parameters correspond to the estimate of the effect of each independent variable on the logarithm of the ratio of probabilities of success/failure 
Table 3 Determinants of product innovation Source Author calculations based on the 2014 ESIDET, INEGI

\begin{tabular}{llll}
\hline Independent variables & Model 1 & Model 2 & Model 3 \\
\hline \% of US imports from China & $0.0548(-3.83)^{* *}$ & $0.035(-4.38)^{* *}$ & $0.0402(-3.75)^{* *}$ \\
\% of US imports from China squared & $18.4782(2.06)^{*}$ & $78.4058(3.02)^{* *}$ & $255.6942(3.52)^{* *}$ \\
Internal competition measure & - & $10.4025(3.06)^{* *}$ & $15.0211(3.15)^{* *}$ \\
Internal competition measure squared & - & $0.0207(-4.04)^{* *}$ & $0.0203(-3.64)^{* *}$ \\
Firm with 100\% foreign capital & - & - & $0.6867(-1.90)^{\wedge}$ \\
Firm with mixed capital & - & - & $0.7678(-1.07)$ \\
Exporting firm & - & - & $1.0738(0.54)$ \\
Outsourcing firm & - & - & $0.7552(-0.94)$ \\
Firm within a corporation & - & - & $1.5098(3.22)^{* *}$ \\
Size & - & - & $1.0000(2.52)^{* *}$ \\
Firm with R\&D area & - & No & $21.1966(23.47)^{* *}$ \\
Industry fixed effects & No & 0.0184 & No \\
Pseudo R-squared & 0.0108 & 0 & 0.1896 \\
Prob $>x^{2}$ & 0 & 6378 & 0 \\
Number of observations & 6378 & & 6378 \\
\hline
\end{tabular}

Each estimation is from a separate logistic regression

A model including industry fixed effects and all control variables included in Model 3 can be found in Table 6

$t$ values are included in parenthesis

* Significant at a $5 \%$ level

** Significant at a $1 \%$ level

$\wedge$ Significant at a $10 \%$ level

(odds ratio). Accordingly, the factor $\mathrm{e}^{\left(\beta_{i}\right)}$ corresponds to the effect of the variable $i$ on the success/failure odds ratio. Thus, a positive value of $\beta_{i}$ corresponds to the value $\mathrm{e}^{\left(\beta_{i}\right)}$ bigger than the unit, which indicates that this particular category has a positive effect on the odds ratio and therefore on the probability of success. Next, the estimated results for each of the following dependent variables are presented: (1) product innovation, (2) process innovation and (3) innovation for the world.

\section{Results}

\subsection{Product innovation}

Table 3 includes three different models to estimate the effect of the independent variables on product innovation at the firm level. The first model includes the percentage of US imports coming from China, at the industry level, and this percentage squared, as the only regressors. The second model adds the internal competition measure as a regressor, as well as said variable squared. We want to see if the Aghion et al. (2005) prediction regarding an inverse U-curve relationship between innovation efforts and competition holds. In the third model, we include all the independent variables that were described above to the regression. This model includes independent dummy variables to identify the companies with $100 \%$ foreign capital, companies with mixed capital (the national companies are the omitted category), exporting companies, outsourcing companies, firms that are part of a corporation, and those with an R\&D laboratory. This last variable is used to take into account the innovative efforts of the production units since the presence of such an area clearly affects the results of innovation; and without them, 
it could cause omitted variable bias. The size of the firm (in terms of personnel) is also included as a continuous independent variable.

The results of Model 1 in Table 3 indicate that when competition with China increases at the industry level, Mexican manufacturing firms react by first decreasing their efforts in product innovation and then increasing them strongly. This means that the Schumpeterian effect holds when competition begins, but afterward, the Escape-Competition effect dominates. Both effects are significant (at the $1 \%$ level and at the $5 \%$ level), but the insertion of the other control variables in the regression is needed to test the robustness of the significance and the sign of the China effect found in this first regression.

In the Model 2, the internal competition variables (both the linear and the quadratic terms) are added to the regression. It is worth noting that internal competition and the innovation results of the firms show an inverted-U curve relationship, as Aghion et al. (2005) predict. As internal competition in the industry intensifies, the innovative efforts of the firms increase but at a decreasing rate. This evidence supports the inverted-U curve relationship between measures of competition and innovation. The second regression also shows that if competition with China increases at the industry level, firms react by first decreasing innovation efforts; however, this is only up to a certain point until innovation starts to increase again. In other words, we find a U-curve relationship between foreign competition and the innovation effort of the firms. Given that the positive relationship with the China effect squared is much larger than the negative effect that holds with the linear China effect term, we could argue that the Escape-Competition effect dominates in the relationship between innovation and foreign competition.

When the rest of the explanatory variables are included in Model 3, the sign and the significance of the China effect prevails, as well as the sign and significance of the China effect squared. This is also the case with the internal competition measure and with the internal competition measure squared. This means that we find strong evidence of an inverted-U curve relationship between internal competition and innovation as well as a strong U-curve relationship between foreign competition and the innovation efforts of the firms. The values of the coefficients indicate that after a drawback in the innovation results, Mexican firms that face competition with China in the US market are 25,569.42\% more likely to innovate than firms that do not face competition with China in the US market. Unfortunately, this coefficient cannot be compared to what other scholars find, because none of the papers reviewed use logistic regression models. Only Gorodnichenko et al. (2010) use binary self-reported innovation dependent variables, but they estimate probit regressions. The rest of the regression coefficients indicate that the companies with $100 \%$ foreign capital are $31.33 \%$ less prone to innovate than the companies with $100 \%$ national capital (the omitted category) and also less than the companies with a mixed capital. In fact, we find that the companies with mixed capital innovate in product as much as the national capital firms. In this first exercise, the exporting companies do not seem more likely than non-exporting firms to innovate, while firms that are part of a corporation are $50.98 \%$ more prone to innovate than companies that are not part of a corporation. Firms with an R\&D laboratory are $2119.66 \%$ more inclined to innovate in products than firms without an $R \& D$ laboratory, while outsourcing companies do not innovate more or less than the non-outsourcing companies. This regression also indicates that larger firms are slightly more innovative than their smaller counterparts. 
Table 4 Determinants of process innovation Source Author calculations based on the 2014 ESIDET, INEGI

\begin{tabular}{llll}
\hline Independent variables & Model 1 & Model 2 & Model 3 \\
\hline \% of US imports from China & $0.0782(-2.63)^{* *}$ & $0.0515(-3.02)^{* *}$ & $0.0401(-2.96)^{* *}$ \\
\% of US imports from China squared & $3.7434(0.7)$ & $12.5283(1.31)$ & $72.5646(2.07)^{*}$ \\
Internal competition measure & - & $15.3271(2.82)^{* *}$ & $15.5551(2.56)^{* *}$ \\
Internal competition measure squared & - & $0.0213(-3.20)^{* *}$ & $0.04(-2.43)^{*}$ \\
Firm with 100\% foreign capital & - & - & $0.6916(-1.60)$ \\
Firm with mixed capital & - & - & $0.7083(-1.20)$ \\
Exporting firm & - & - & $1.5996(3.09)^{* *}$ \\
Outsourcing firm & - & - & $0.9282(-0.23)$ \\
Firm within a corporation & - & - & $1.5005(2.66)^{* *}$ \\
Size & - & - & $1.0000(0.82)$ \\
Firm with R\&D area & - & - & $19.2848(21.04)^{* *}$ \\
Industry fixed effects & No & No & No \\
Pseudo $R$ squared & 0.0153 & 0.0199 & 0.2026 \\
Prob $>X^{2}$ & 0 & 0 & 0 \\
Number of observations & 6378 & 6378 & 6378 \\
\hline Eah & & &
\end{tabular}

Each estimation is from a separate logistic regression

$t$ values are included in parenthesis

* Significant at a $5 \%$ level

** Significant at a $1 \%$ level

Competition with China in the US market appears to be the most important determinant of product innovation results in Mexican companies followed by the presence of an R\&D laboratory. This means that Mexican firms that compete for a share of the US market and have an internal $R \& D$ area are the most prone to generate product innovations in the country. The following section presents the results for the process innovation estimations.

\subsection{Process innovation}

Table 4 includes three different models to estimate the effect of the independent variables on the process innovation results of the Mexican manufacturing firms. The first regression (Model 1) only includes the China effect (i.e., the percentage of US imports coming from China at an industry level) and the China effect squared as independent variables. This first regression shows that as an industry faces more competition with China in the US market, the process innovation results of Mexican manufacturing firms decrease. In this model, we do not find evidence of a U-curve relationship between external competition and process innovation. In the second regression (Model 2), we include the internal competition measure and its square as regressors. As in the first regression, we do not find a U-curve relationship between external competition and process innovation in the second regression. These results suggest that as competition with China for the US market increases, Mexican firms decrease process innovation results. This means that a Schumpeterian effect dominates.

Additionally, we find an inverted- $U$ curve relationship between internal competition and process innovation results. The China effect and the inverted-U relationship hold after the other control variables are included in the regression (Model 3). 
Table 5 Determinants of innovations for the world Source Author calculations based on the 2014 ESIDET, INEGI

\begin{tabular}{llll}
\hline Independent variables & Model 1 & Model 2 & Model 3 \\
\hline \% of US imports from China & $0.0301(-3.89)^{* *}$ & $0.0221(-4.18)^{* *}$ & $0.0669(-2.81)^{* *}$ \\
\% of US imports from China squared & $45.6124(2.26)^{*}$ & $113.814(2.74)^{* *}$ & $68.5205(2.35)^{* *}$ \\
Internal competition measure & - & $6.8388(2.12)$ & $10.9966(2.47)^{* *}$ \\
Internal competition measure squared & - & $0.0634(-2.47)^{* *}$ & $0.0434(-2.64)^{* *}$ \\
Firm with 100\% foreign capital & - & - & $0.4977(-2.67)^{* *}$ \\
Firm with mixed capital & - & - & $0.8745(-0.49)$ \\
Exporting firm & - & - & $0.4088(-4.98)^{* *}$ \\
Outsourcing firm & - & - & $0.3815(-1.51)$ \\
Firm within a corporation & - & - & $1.5144(2.89)^{* *}$ \\
Size & - & - & $1.0000(2.62)^{* *}$ \\
Firm with R\&D area & - & - & $12.4316(17.11)^{* *}$ \\
Industry fixed effects & No & No & No \\
Pseudo $R$ squared & 0.0127 & 0.0154 & 0.1339 \\
Prob $>X^{2}$ & 0.0000 & 0.0000 & 0.0000 \\
Number of observations & 6378 & 6378 & 6378 \\
\hline
\end{tabular}

Each estimation is from a separate logistic regression

$z$ values are included in parenthesis

* Significant at a $5 \%$ level

** Significant at a $1 \%$ level

In this case, firms that engage in exporting, form part of a corporation, and those with an R\&D laboratory are more prone to innovate. Exporting firms are 59.96\% more prone to innovate than non-exporting firms; firms within a corporation are $50.05 \%$ more inclined to innovate than non-corporation firms; and firms with an R\&D laboratory are $1928.48 \%$ more likely to innovate than firms without an R\&D laboratory. Conversely, firms with foreign and mixed capital do not seem more inclined to innovate when compared to firms with only national capital, and outsourcing firms are not more likely to innovate when compared to non-outsourcing firms. In this regression, firm size does not make a statistically significant impact on the process innovation results.

Once again, the most important variable behind the process innovation results in Mexican manufacturing firms seems to be competition with China in the US market. The size of the coefficient in Model 3 indicates that firms competing with the China in the US market are $7256.46 \%$ more likely to innovate in processes than firms that do not face this kind of competition. The second most important determinant of process innovation results is the presence of an R\&D laboratory. The size of the coefficient of the internal competition variable in Model 3 indicates that more internal competition makes firms $1555.51 \%$ more inclined to innovate in processes than their counterparts that sell in more concentrated markets. This means that Mexican firms that compete with Chinese firms in the US market are the most inclined to innovate in process, which is driven by a need to reduce production costs. In the following section, we discuss the results of the innovation for the world regressions. 


\subsection{Innovation for the world}

Table 5 includes three different models to analyze the effect of the independent variables on innovation for the world. The independent variables of each model are the same as in the previous regressions. The first column (Model 1) of Table 5 indicates that as competition with China for the US market increases, the innovative efforts of Mexican manufacturing firms increase after a brief initial period of reduced innovation. This means that, once again, we find a U-curve relationship between external competition and innovation results. This effect holds for the different specifications, showing robustness. Given the sizes of the coefficients of the linear and squared terms, it is easy to conclude that the Escape-Competition effect dominates the Schumpeterian effect. The internal competition measure also shows the inverted-U curve that Aghion et al. (2005) predict. This result holds true even when all of the control variables are included in the model.

Regarding the size of the coefficients, Model 3 of Table 5 shows that firms competing with China within the US market are $6852.05 \%$ more prone to innovate for the world than firms not competing with China. Additionally, firms with an R\&D area are $1243.16 \%$ more inclined to innovate for the world when compared to firms without an $\mathrm{R} \& \mathrm{D}$ area. The rest of the results are discussed below.

Firms with foreign capital seem to innovate $49.77 \%$ less than the mixed and national capital companies, and mixed capital firms do not seem to innovate more or less than their national capital counterparts. Exporting firms tend to innovate for the world 59.12\% less than their non-exporting counterparts, while firms that are part of a corporation are $51.44 \%$ more prone to innovate for the world. In this model, outsourcing firms do not seem less prone to innovate when compared to non-outsourcing firms. Regarding the size of the firms in personnel, the results indicate that as firms grow, they tend to generate slightly more innovations for the world.

In order to further test the robustness of our results, the following section presents three logistic regressions with industry fixed effects added.

\subsection{Robustness checks}

In this section, we carry out logistic regressions with industry fixed effects at a two-digit level for each of the three dependent variables to verify the robustness of the results. Regressions for each industry are also estimated, but in many cases, the competition with China variable is omitted because it perfectly predicts success in innovation results.

Table 6 shows the results of the three regressions conducted. The same control variables of Model 3 in the previous section are included in the estimations. Table 6 shows that the significance and sign of the variables regarding competition with China and internal competition are basically identical to those found before. The U-effect of competition with China still holds, suggesting that the Escape-Competition effect dominates the initial Schumpeterian effect. Moreover, the inverted-U effect of competition that Aghion et al. (2005) predict also holds, even when controlling for the characteristics that different industries and firms may have. Exporting firms appear to promote process innovation more than they appear to promote innovation for the world. This phenomenon is also addressed by Meza-González (2017). The presence of an R\&D area inside the firm and being part of a corporation are also positively correlated with the 
Table 6 Logistic regressions with fixed effects by industry Source Author calculations based on the 2014 ESIDET, INEGI

\begin{tabular}{llll}
\hline Independent variables & Product innovation & Process innovation & Innovation for the world \\
\hline \% of US imports from China & $0.0198(-4.23)^{* *}$ & $0.0201(-3.32)^{* *}$ & $0.0406(-3.05)^{* *}$ \\
\% of US imports from China squared & $751.6868(3.99)^{* *}$ & $209.4121(2.46)^{* *}$ & $144.9737(2.62)^{* *}$ \\
Internal competition measure & $12.8242(2.94)^{* *}$ & $13.0329(2.37)^{* *}$ & $9.7436(2.33)^{*}$ \\
Internal competition measure squared & $0.0236(-3.47)^{* *}$ & $0.0476(-2.27)^{*}$ & $0.0490(-2.52)^{* *}$ \\
Firm with 100\% foreign capital & $0.0666(-2.05)^{*}$ & $0.6737(-1.71)^{\wedge}$ & $0.4852(-2.76)^{* *}$ \\
Firm with mixed capital & $0.7525(-1.15)$ & $0.6964(-1.26)$ & $0.8579(-0.56)$ \\
Exporting firm & $1.0429(0.32)$ & $1.5508(2.86)^{* *}$ & $0.3992(-5.08)^{* *}$ \\
Outsourcing firm & $0.7468(-0.98)$ & $0.9185(-0.26)$ & $0.3805(-1.51)$ \\
Firm within a corporation & $1.4956(3.14)^{* *}$ & $1.4857(2.59)^{* *}$ & $1.5093(2.86)^{* *}$ \\
Size & $1.0000(2.52)^{* *}$ & $1.0000(0.78)$ & $1.0000(2.62)^{* *}$ \\
Firm with R\&D area & $20.7961(23.28)^{* *}$ & $18.9280(20.86)^{* *}$ & $12.2432(16.96)^{* *}$ \\
Industry fixed effects & Yes & Yes & Yes \\
Pseudo $R$ squared & 0.1906 & 0.2035 & 0.0000 \\
Prob $>X^{2}$ & 0.0000 & 6378 & 0.1344 \\
Number of observations & 6378 & 0.0000 \\
\hline
\end{tabular}

Each estimation is from a separate logistic regression

$z$ values are included in parenthesis

* Significant at a $5 \%$ level

** Significant at a $1 \%$ level

$\wedge$ Significant at a $10 \%$ level

three different kind of innovations analyzed. National firms appear to be more prone to innovate than their foreign counterparts, while larger firms seem slightly more inclined to innovate in comparison to smaller firms. The following section includes concluding remarks and a discussion of policy implications.

\section{Conclusions and policy implications}

The effects of China's economic growth on Mexico and LAC have important implications for regional policy makers. Although the idea that LAC is losing FDI to China is commonly held, particularly for manufacturing, China's emergence as a major world exporter has brought an increase in Chinese FDI to the region. After China joined the WTO in 2001, LAC countries worried about losing global market share. Due to China and LAC's distinct export profiles, LAC countries' global market shares have not been greatly affected by Chinese competition. Mexico was the exception since, like China, it specializes in manufactured goods. Increased imports from China have affected the labor market by lowering employment and wages. It is important to consider these factors when planning economic development and trade policies for LAC countries. To protect local economies and labor markets, policymakers should promote high-value manufacturing and diversify economic activities.

The question of whether competition with China in the US market impacts innovation in Mexican manufacturing firms is essential for understanding what motivates Mexican manufacturing firms to innovate. Innovation is important because it leads to greater productivity, economic prosperity, and efficiency. Empirical research (Alvarez and Robertson 2004; Meza-González 2017) shows that Mexican manufacturing firms that engage 
in exporting tend to innovate more than their domestic-oriented counterparts. This is likely due to competition faced abroad and the need to decrease costs (Meza-González 2017).

Considering the theory on competition and innovation, we expected that Mexican manufacturing firms facing competition from China for US market share would be more innovative; however, this was not the case during the initial stages of the introduction of Chinese products into the US market. Instead, we found a U-curve relationship between international competition and innovation, with the positive effect being stronger than the negative. This suggests that although the Escape-Competition effect dominates, there is a Schumpeterian effect in the initial stages of the insertion of China in the US market. Aghion et al. (2005) argue that firms with different levels of technological sophistication that compete in a certain market are more likely to experience a negative relationship between competition and innovation, because laggard firms tend to withdraw from the market, leaving leaders with little incentive to innovate. However, as competition is faced between more neck-and-neck firms, i.e., firms with similar levels of technological sophistication, the incentives to innovate increase because more competition may reduce the firm's pre-innovation rents by more than it reduces its post-innovation rents. This idea is consistent with the hypothesis that Mexican and Chinese firms are different in terms of technological sophistication at the initial stages of the competition for the US market, but after laggard firms withdraw, Mexican and Chinese firms seem to compete in a more neck-and-neck fashion.

According to our results, the US industries where Mexican and Chinese firms compete for market share could be considered technologically unleveled at the early stages of competition because Mexican manufacturing firms initially react by decreasing their innovation efforts. This may suggest that at first, Mexican firms consider the market lost, and as a result, the technological laggards withdraw. After a period of caution and discouragement, only Mexican firms that are technologically neck-and-neck with Chinese firms remain in the market. At that point, innovation among Mexican manufacturing firms starts to increase in order to escape competition from China. This prediction aligns with the results of Bloom et al. (2016) empirical study, which finds competition from China in Europe leads to increased innovation among European countries. However, in the initial stages of growing foreign competition, the results align with Hashmi (2013) findings, i.e., a "mildly negative" relationship characteristic of the Schumpeterian Effect between product market competition and innovation.

Based on these findings, the Mexican government should consider the implementation of tax exemptions and/or subsidies for firms that are competing with China in the US market. The effect of competition with China on innovation should also be considered in the negotiations of trade agreements with countries where China is an important provider of goods through imports. It is likely that Mexican exporters face high levels of competition in the world market either from China or from other manufacturing leaders. These firms are the most probable to generate innovations for the firm, the country, and for the world. CONACYT (the National Council for Science and Technology) is the institution in charge of promoting technological advancement in Mexico, and it must be aware of the processes that boost innovation results in addition to fiscal incentives. The Ministry of Public Education (SEP) and universities also play key roles in promoting 
technological advancement in Mexico and should be prepared to train the labor force to meet the staffing needs of firms engaging in innovation. Promoting innovation is a viable path to generate higher economic growth rates in a country currently characterized by mediocre growth.

The various theories regarding the relationship between competition and innovation attest to the difficulty in studying this subject. Challenges include issues with timing, endogeneity, omitted variables, and industry and product life cycles. There could also be a lag between competition in the market and innovative activities (Aghion et al. 2005), so it is difficult to determine what a sufficient time period is for a study on competition and innovation. By analyzing the China effect and the theory regarding competition and innovation, this research begins to fill a gap in the literature regarding the impact of Chinese competition in the US market on innovation in the Mexican manufacturing sector. Empirical evidence helps to further address the gap in the literature, increase understanding of the relationship between competition and innovation, and aid policy makers to make informed decisions to achieve economic growth.

\section{Acknowledgements}

We thank Raymond Robertson for his support. We also thank the Microdata Laboratory of INEGI for allowing Liliana Meza to estimate the models. We appreciate the support of the Microdata Laboratory at INEGI in the preparation of the database used in this research.

\section{Authors' contributions}

LMG was in charge of the data, methodology and descriptive statistics section and of the econometric estimations and JMS was in charge of the Literature Review and the Theoretical framework of the article. Both authors read and approved the final manuscript.

\section{Funding}

This research did not receive any funding.

\section{Availability of data and materials}

The main data is not available to the public in general because of confidentiality issues. Data is available at the Microdata Laboratory of the National Institute of Statistics and Geography (INEGI), Mexico.

\section{Competing interests}

The authors declare that they have no competing interests.

\section{Author details}

${ }^{1}$ INEGI and Universidad Iberoamericana, Mexico City, Mexico. ${ }^{2}$ Texas A\&M University, College Station, USA.

Received: 4 December 2018 Accepted: 17 May 2019

Published online: 29 May 2019

\section{References}

Aghion P, Griffith R (2005) Competition and growth: reconciling theory and evidence. MIT Press, Cambridge Aghion $P$, Howitt P (1992) A model of growth through creative destruction. Econometrica 60(2):323-51

Aghion P, Bloom N, Blundell R, Griffith R, Howitt P (2005) Competition and innovation: an inverted-U relationship. Q J Econ 120:701-728

Alvarez R, Robertson R (2004) Exposure to foreign markets and plant-level innovation: evidence from Chile and Mexico. J Int Trade Econ Dev 13(1):57-87

Arrow K (1962) Economic welfare and the allocation of resources for inventions. In: Nelson R (ed) The rate and direction of inventive activity. Princeton University Press, Princeton

Baily MN, Gersbach H (1995) Efficiency in manufacturing and the need for global competition. Brookings Papers Econ Act Microecon 1995:307-347

Becheikh N, Landry R, Amara N (2006) Lessons from innovation empirical studies in the manufacturing sector: a systematic review of the literature from 1993-2003. Technovation 26(2006):644-664

Bloom N, Draca M, Van Reenen J (2016) Trade induced technical change? The impact of Chinese imports on innovation, IT and productivity. Rev Econ Stud 83(1):87-117

Blundell R, Griffith R, Van Reenen J (1999) Market share, market value and innovation in a panel of British manufacturing firms. Rev Econ Stud 66:529-554

Caamal-Olvera CG, Rangel-González E (2015) Measuring the impact of the Chinese competition on the Mexican Labor Market: 1990-2013. Noth Am J Econ Finance 34:351-363 
Carlin W, Schaffer M, Seabright P (2004) A minimum of rivalry: evidence from transition economies on the importance of competition for innovation and growth. Contrib Econ Anal Policy 3(1):1-43

Chen Z (2017) Product market competition and innovation: what can we learn from economic theory? Front Econ China 12(3):450-464. https://doi.org/10.3868/s060-006-017-0019-2

Dixit A, Stiglitz J (1977) Monopolistic competition and optimum product diversity. Am Econ Rev 67:297-308

Gallagher K, Porzecanski R (2008) China matters: China's economic impact in Latin America. Latin Am Res Rev 43(1):185-200

Gilbert R, Newbery D (1982) Preemptive patenting and the persistence of monopoly. Am Econ Rev 72:514-526

Gorodnichenko Y, Svejnar J, Terrell K (2010) Globalization and innovation in emerging markets. Am Econ J Macroecon 2(2):194-226. https://doi.org/10.1257/mac.2.2.194

Hashmi AR (2013) Competition and innovation: the inverted-U relationship revisited. Rev Econ Stat 95(5):1653-1668

Kamien M, Schwartz N (1972) Timing of innovations under rivalry. Econometrica 40:43-60

Lall S, Weiss J (2007) China and Latin America: trade competition, 1990-2002. In: Santiso J (ed) The visible hand of China in Latin America. OECD Publishing, Paris, pp 85-108

Ma AC, Wooster RB (2009) The effects of US-China trade on employment and wages in the US-Mexico border region. Contemp Econ Policy 27(3):335-348

Mendoza Cota JE (2016) US manufacturing imports from China and employment in the Mexican manufacturing sector. Cuadernos de Economía 35(69):583-613

Meza-González L (2017) Internationalization and the creation of new products and processes in the Mexican manufacturing industry. Econ World 5(3):195-212

OECD (1997) Proposed guidelines for collecting and interpreting technological innovation data. Oslo Manual. Ed. OECD and Eurostat. Paris

Romer P (1990) Endogenous technological change. J Polit Econ 98:71-102

Salop S (1977) The noisy monopolist: imperfect information, price dispersion, and price discrimination. Rev Econ Stud 44:393-406

Sargent J, Matthews L (2009) China versus Mexico in the global EPZ industry: maquiladoras, FDI quality, and plant mortality. World Dev 37(6):1069-1082

Scherer F (1967) Market structure and the employment of scientists and engineers. Am Econ Rev 57:191-213

Schumpeter JA (1943) Capitalism, socialism and democracy. London: Allen and Unwin, reprinted 1976

\section{Publisher's Note}

Springer Nature remains neutral with regard to jurisdictional claims in published maps and institutional affiliations.

\section{Submit your manuscript to a SpringerOpen ${ }^{\odot}$ journal and benefit from:}

- Convenient online submission

- Rigorous peer review

- Open access: articles freely available online

- High visibility within the field

- Retaining the copyright to your article

Submit your next manuscript at $\mathbf{s p r i n g e r o p e n . c o m ~}$ 